\title{
RECENZJE
}

\section{Odpowiedź na recencję prof. Ilony Czamańskiej}

doi.org/10.14746/bp.2017.24.14

W tomie 23 „Balcanica Posnaniensia” ukazała się napisana przez prof. Ilonę Czamańską recenzja mojej książki zatytułowanej Trzy oblicza Sawy Nemanjicia: postać historyczna-autokreacja-postać literacka, z którą zapoznałem się z niemałym zaciekawieniem. Korzystając z prawa autora do odpowiedzi na recenzję, pozwalam sobie ustosunkować się do kilku kwestii w niej poruszonych. Dla zachowania przejrzystości moich wywodów do poszczególnych wątków, odnoszę się w takiej kolejności, $\mathrm{w}$ jakiej pojawiły się w recenzji.

Recenzentka napisała m. in., że: „Ostatnio w historiografii bałkańskiej pojawiła się teza, że Miroslav i Nemanja byli spokrewnieni jedynie przez matkę" (s. 211). Tymczasem hipoteza taka została przedstawiona po raz pierwszy w artykule Stanoja Stanojevicia z 1930 r. ${ }^{1}$, a w 1958 r. została powtórzona z nowymi argumentami przez Đorđa Sp. Radojičicia ${ }^{2}$. Wedle mojej wiedzy, od tamtej pory pogląd ten nie pojawił się już w opracowaniach bałkańskich, a jedynie w haśle słownikowym autorstwa Jana Leśnego $^{3}$. Zresztą polski uczony po kilku latach wycofał się z tego poglądu wobec poszerzenia dostępnych nauce zasobów źródłowych ${ }^{4}$.

W recenzji znalazł się także akapit:

Podobnie niejasna dla Autora w świetle źródeł wydaje się postać Tihomira dość powszechnie uznawana za najstarszego brata Nemanji. Wątpliwości Autora są zrozumiałe, źródła średniowieczne bardzo rzadko pozwalają na jednoznaczną interpretację. Niemniej jednak przydało by się dodać, że są to problemy przez cały czas dyskusyjne w nauce i popularność jakiejś tezy w opracowaniach podręcznikowych tej dyskusji bynajmniej nie zamyka. (s. 211-212)

Chciałbym zauważyć, że w swojej książce Tihomira wspomniałem dokładnie jeden raz, i to w zupełnie innym kontekście. Domyślam się więc, że słowa Recenzentki odnoszą się nie do książki, a do mojego artykułu wydrukowanego w tym samym to-

\footnotetext{
${ }^{1}$ Ст. Станојевић, О Немањином оиу, „Старинар“, 1930, t. 5, s. 5.

2 Ђ.Сп. Радојичић, Завида, отаи хумског кнеза Мирослава, „Јужнословенски филолог”, 23/1-4 [1958], s. 258.

${ }^{3}$ J. Leśny, Zavida [w:] Słownik starożytności stowiańskich: encyklopedyczny zarys kultury Stowian od czasów najdawniejszych do schytku wieku XII, t. VII, cz. 1: Y-Ż, red. G. Labuda, Z. Stieber, Wrocław 1982, s. 92-93.

${ }^{4}$ J. Leśny, Stefan Zawida syn Urosza I ojcem Stefana Nemani, „Roczniki Historyczne” 54 [1988], s. 67.
} 
mie czasopisma co recenzja 5 . Jako że temat został jednak poruszony, wypada się doń ustosunkować. Otóż przez 60 lat poprzedzających publikację mojego artykułu jedynym, który kwestionował (w początkach XXI wieku) podważane przeze mnie sądy, jest Živojin Andrejić, którego prace są ignorowane przez resztę serbskich historyków ze względu na bezkrytyczne podejście do źródeł powstałych 200-500 lat po wydarzeniach. Co więcej, możliwe, że sądów tych nie kwestionował nikt przez cały XX wiek, choć tu - przyznaję - do niektórych starszych publikacji, nie dotarłem. Wydaje mi się zatem, że bardziej uzasadnione jest nazywanie tych sądów ,ugruntowanymi poglądami”, jak to uczyniłem, niż „,problemami dyskusyjnymi”, jak sugeruje Recenzentka. Pragnę jeszcze dodać, że występują one nie tylko w podręcznikach, ale również w szczegółowych opracowaniach, co widać zresztą w przypisach do mojego artykułu.

Według Recenzentki z niewymienienia Trawunii (w odróżnieniu od Zety i Humu) w przywileju dla kupców splickich nie należy raczej wyciągać wniosku, że nie znajdowała się jeszcze w granicach państwa Nemanji (jak to uczyniłem), ponieważ „Wydaje się też, że prawdopodobnie Hum, a z całą pewnością Zeta, niezależnie od ich faktycznego podporządkowania przez Nemanję, były w końcu XII wieku traktowane jak osobne państwa, dlatego też zostały one wyszczególnione w dokumencie" (s. 212). Chociaż istnieje możliwość (źródła dostarczają niewiele danych), że Zetę i ewentualnie Hum traktowano pod koniec XII wieku jak osobne państwa, to przy ocenie rozważań zawartych w mojej książce nie ma to jednak znaczenia. Istotne jest tylko to, czy były tak traktowane w momencie wystawienia ww. przywileju, a to można sprawdzić wyłącznie, analizując treść tego dokumentu. Zaczyna się on słowami: „Ja wielki żupan Stefan Nemanja zezwalam splicianom swobodnie wchodzić do mojej ziemi i syna mojego Rastka, do humskiej ziemi, i syna mojego Vuka(na), do Zety"6, po czym następuje szczegółowy opis praw przysługujących kupcom splickim. Warto zwrócić uwagę na dwa elementy. Po pierwsze, jest to najstarsze znane nauce źródło, w którym Hum jest nazwany „humską ziemią”, a nie tak jak dotychczas Zahumljem (Zachlumiem). Może to wskazywać na zmianę statusu tego obszaru z państwowego na jednostkę administracyjną lub terytorialną w obrębie większego państwa ${ }^{7}$. Po drugie, Nemanja samodzielnie podejmuje decyzję obowiązującą również w Zecie rządzonej przez jego syna, co bardziej przypomina traktowanie tego terytorium jako dzielnicy czy apanażu

${ }^{5}$ B. Szefliński, O tajemniczym poprzedniku wielkiego żupana Stefana Nemanji zwanym Tihomirem, „Balcanica Posnaniensia” 23 [2016], s. 35-45.

${ }^{6}$ Tłumaczę najszerzej przyjmowaną rekonstrukcję: Г. Ружичић, Три старе српске повеље, „Зборник за филологију и лингвистику”, 4-5 [1961-1962], s. 294. Według rekonstrukcji Borislava Radojkovicia pomiędzy słowami „Rastka” oraz „do” znajduje się jeszcze spójnik „i”. Б. Радојковић, Немањина повеља Сплићањима, „Историски записи” 13/1-2 [1957], s. 125.

${ }^{7}$ С. Мишић, Хумска земља, назив и жупе, w: Епископија захумско-хериеговачка, прир. С. Ћосовић, Београд 2006, s. 39-40, 42. Ten sam autor pisał również o ziemi humskiej jako jednostce terytorialno-administracyjnej: С. Мишић, Историјска географија српских земаља: од 6. до половине 16. века, Београд 2014, s. 66. Ogólnie o ,ziemi” jako jednostce terytorialno-administracyjnej: С. Мишић, , Земља” у држави Немањића, „Годишњак за друштвену историју” 4/2-3 [1997], s. 133-146. 
niż jako odrębnego państwa ${ }^{8}$. To samo dotyczy ziemi podległej Rastkowi, którą była ziemia humska lub inna, niewymieniona z nazwy w dokumencie.

Wątpliwości Recenzentki dotyczące okoliczności śmierci Streza przekonują mnie o konieczności poświęcenia małej wiarygodności relacji Teodozjusza Chilandarskiego na ten temat (na które to źródło Recenzentka się powołuje) osobnej pracy, co prawdopodobnie w niedalekiej przyszłości uczynię. W tym miejscu zajmę się tylko kwestią modlitwy Sawy poruszoną w recenzji. Według Teodozjusza Sawa pomodlił się do Boga, by pokarał Streza, i jeszcze tej samej nocy życie władcy dobiegło końca, co zdaniem Recenzentki nie było przypadkiem. Następnie Recenzentka dodaje:

Modlitwy św. Sawy miały przecież niekiedy dość specyficzny charakter, były np. niezbędne do utrzymywania stałego wycieku mirry z ciała św. Symeona. Niewątpliwie musiał on posiadać pewną wiedzę praktyczną w zakresie alchemii. (s. 212)

Należy pamiętać, że dzieło Teodozjusza powstało jakieś sześćdziesiąt lat po śmierci Streza, a jego autor nie był świadkiem żadnej z modlitw Sawy. Z tego powodu brzmienie modlitw, a co za tym idzie, ich ewentualne powiązanie $\mathrm{z}$ wydarzeniami, należy raczej traktować jako odzwierciedlenie przekonań hagiografa. A że nie istniało pod niebem nic, czego Teodozjusz nie byłby w stanie powiązać z modlitwą Sawy, pokazuje następujący fragment jego dzieła:

tak że i prostym ludziom po domach i w górach pasającym stada, gdy otrzymywali mleko, nie potrzeba było podpuszczki, tylko powiedzieć „,niech modlitwa Sawy cię skiśnie” - i zaraz więc na to słowo robił się ser, a mleko stawało kwaśne i bardzo dobre9.

$\mathrm{Z}$ tego powodu uważam, że należy zachować daleko posuniętą rezerwę w stosunku do treści modlitw zapisanych u Teodozjusza, a zwłaszcza wtedy, gdy źródła bliższe wydarzeniom przekazują w tym samym kontekście modlitwy o odmiennej wymowie. A tak właśnie jest w przypadku śmierci Streza - według Domencjana Sawa modlił się o Bożą pomoc w pokonaniu i przepędzeniu wrogów ${ }^{10}$. Przy okazji chciałbym zauważyć, że nie powinniśmy zakładać, że wonne oleje (mirra) wypływały z ciała św. Symeona, i to z dwóch powodów. Po pierwsze, źródła mówią o ich wypływaniu z sarkofagu i portretu na ścianie, a nie $\mathrm{z}$ ciała ${ }^{11}$. Po drugie, analiza porównawcza opisów ziemskich pozostałości świętych w różnych hagiografiach wskazuje, że najprawdo-

${ }^{8}$ Zetę pod rządami Vukana jako dzielnicę postrzegał też Miloš Blagojević, który w swoich badaniach nie korzystał jednak z analizowanego tu dokumentu: М. Благојевић, Немањићи и државност Дукље - Зете - Црне Горе, „Зборник Матице српске за историју” 83 [2011], s. 15-17.

9 Доментијан [=Теодосије Хиландарац], Житије светог Саве, изд. Ђ. Даничић, Биоград 1860, s. 115 .

10 Доментијан, Житије Светога Саве, прир., прев. и комент. Љ. Јухас-Георгиевска, изд. Т. Јовановић, Београд 2001, s. 175-179.

${ }^{11}$ Стефан Првовенчани, Сабрана дела, прир., прев. и комент. Љ. Јухас-Георгиевска, изд. Т. Јовановић, Београд 1999, s. 76-77, 102-103; Доментијан, op. cit., s. 155-156, 192-194; Доментијан [=Теодосије Хиландарац], op. cit., s. 87-88, 122-123. 
podobniej św. Symeon nie został po zakończeniu życia zabalsamowany, a co za tym idzie, ponad 10 lat po jego śmierci z ciała raczej nie za wiele zostało ${ }^{12}$. Właściwszym określeniem wydają się więc „kości” lub, bardziej oględnie, „szczątki” tudzież „,relikwie". Nie wydaje mi się też, aby uprawniony był w tym kontekście wniosek, że Sawa znał się na alchemii (choć niewykluczone, że wiedzę w tym zakresie posiadał). Racjonalnie bowiem spoglądając na tę kwestię, do obsługi instalacji rozprowadzającej olej wystarczyła zapewne wiedza techniczna z - jak byśmy dzisiaj powiedzieli dziedziny hydrauliki.

Kolejnym wątkiem poruszonym przez Recenzentkę jest sprawa koronacji królewskiej Stefana. W recenzji można przeczytać, że:

Domentian pisał o otrzymaniu przez Stefana Nemanjicia korony od papieża, Teodozje o uroczystej koronacji dokonanej przez św. Sawę w obrządku prawosławnym. Autor niesłusznie pisze, że informacja Domentiana nie znajduje nigdzie potwierdzenia. Wspomina o tym wydarzeniu diakon Tomasz ze Splitu (s. 212-213);

po czym następuje cytat ustępu ze źródła mówiącego o uzyskaniu przez Stefana korony z Rzymu i koronacji przez legata papieskiego. Jedyne zdanie w mojej książce, do którego może się odnosić zarzut Recenzentki, brzmi:

Zgoda papieża na koronację Stefana przez prawosławnego arcybiskupa wydaje się czymś nieprawdopodobnym, ale Domencjan twierdzi, że miała miejsce, a nie dysponujemy żadnym źródłem, które pozwalałoby wiarygodność jego przekazu w tym względzie podważyć. (s. 120).

Pisałem, jak widać, o zgodzie papieża na koronację przez prawosławnego arcybiskupa (nie o zgodzie papieskiej w ogóle), a ta informacja rzeczywiście nie występuje w innych źródłach.

Co się natomiast tyczy przedstawionego przez Recenzentkę poglądu, że koronacja Stefana przez legata papieskiego w 1217 r. nie mogła mieć oficjalnego charakteru ze względu na brak własnego hierarchy kościelnego odpowiednio wysokiej rangi (tj. arcybiskupa), to jest to całkowicie nowa koncepcja, moim zdaniem warta rozwinięcia w osobnym artykule $\mathrm{z}$ dwóch powodów. Po pierwsze, ze względu na jej możliwe implikacje dla sporu historyków o liczbę koronacji królewskich Stefana (jedna czy dwie). A po drugie, dlatego, że wymaga dokładniejszego uzasadnienia, ponieważ przedstawiona $\mathrm{w}$ recenzji $\mathrm{w}$ dość zdawkowej formie budzi dwie istotne wątpliwości: 1. W Czechach odbyło się kilka koronacji królewskich, mimo że nie miały własnego arcybiskupa aż do 1344 r., 2. W regeście listu Stefana Pierwokoronowanego do papieża Honoriusza III ten pierwszy jest nazwany koronowanym królem (rex coronatus) ${ }^{13}$. Źródło to pokazuje stan z czwartego roku pontyfikatu tego papieża (24 VII 1219-

12 Д. Поповић, Светитељско прослављање Симеона Немање: прилог проучавању култа моштију код Срба, „Зборник радова Византолошког института” 37 [1998], s. 43-53.

13 F. Rački, Pismo prvovienčanog kralja srbskoga Stjepana I papi Honoriju III 1220. godine, „Starine Jugoslavenske akademije znanosti i umetnosti“" 7 [1876], s. 55. 
23 VII 1220), a więc sprzed koronacji przez Sawę, którą to Recenzentka, jak się zdaje, uważa za oficjalną.

Na koniec chciałbym dodać, że cieszy mnie fakt, iż znawczyni dziejów Bałkanów, jaką jest prof. Ilona Czamańska, zdecydowała się polecić moją książkę Czytelnikom. Jednocześnie żywię nadzieję, że polemika dotycząca mojej książki przyczyni się do zwiększenia zainteresowania sprawami serbskimi w polskiej historiografii, bowiem po odejściu z tego świata Jana Leśnego, Wincentego Swobody i Tadeusza Wasilewskiego polska nauka wyraźnie odczuwa niedobór badań w zakresie historii średniowiecznej Serbii. 